\title{
ON THE TOUCH-EvENT
}

\author{
Theopolitical Encounters
}

\section{Valentina Napolitano}

\begin{abstract}
This article addresses the 'touch-event' as a mediated affective encounter that pivots around a tension between intimacy and distance, seduction and sovereignty, investment and withdrawal. Through a rereading of the Pauline event of conversion to Christianity, it argues that an analysis of the evolving significance of touch-events for Catholic liturgy and a religious congregation shows the theopolitical as always already constituted within an economy of enfleshed virtues. Focusing on contemporary examples of touch-events from the life of Francis, the first pope from the Americas, as well as from fieldwork among a group of female Latin American Catholic migrants in Rome, I argue for a closer examination of touch-events in order to grasp some of their theopolitical, radical, emancipatory, and, in some contexts, subjugating effects.
\end{abstract}

Keywords: Atlantic Return, economies of virtues, incarnation, Pauline event, Pope Francis, sovereignty, theopolitics, touch-event

If one googles the word 'touch-event', what comes up is a definition of a keyword in the Java programming language-TouchEvent-that governs the interface between a given piece of software and a user's contact with a piece of touch-sensitive hardware (e.g., a touchscreen or touchpad). ${ }^{1}$ Although this use of the term is distinct in obvious ways from my own theorization of touchevent in what follows, the Java keyword 'TouchEvent' nevertheless names an infrastructural modality that is at once a tactile, digital encounter (a movement) and a condition for its apprehension (a code). Anthropologists and historians have written at some length about touch—chief touch, royal touch, papal touch, ritual and healing touch-and the connection between the king's two bodies in medieval and early modern concepts of sovereignty (Firth 1940; Graeber and Sahlins 2017; Kantorowicz [1957] 1997). This long-existing literature 
in anthropology has been concerned in particular with issues of kinship, the transmission of power, and connected social formations. The theopolitical, as proposed here, is a moment of disruption that becomes an event within existing infrastructures, but not always an emancipatory one. This article focuses on the theopolitical underpinnings of a particular set of touch-events to better grasp this contradiction.

I wish to explore the touch-event as a mediated affective encounter that pivots around a tension between intimacy and distance, investment and withdrawal. I do this in two ways. First, I provide a brief reflection on the ethical turn in anthropology, in particular the ethical turn in the interpretation of the Pauline event in recent theoretical accounts of cultural rupture, universality, and subject-making. In conversation with this turn in the literature, I argue that a different reading of the Pauline event, foregrounding the touch-event and its attention to enfleshed transformations as part of an economy of virtues, might open us to a clearer recognition of the ineluctable oscillation of intimacy and publicity, and of carnality, as the moment where divine and human are participatory in history. As such, carnality matters for the breaking of the Law and is at the heart of the Pauline event and its message. I then dwell on some Pauline interpretations at length as they have been key to a turn in the anthropology of Christianity toward ethics. I argue this turn needs to be revisited under a rubric of theopolitical and feminist critique.

Second, I examine several concrete examples of touch-events, drawn from my own research and fieldwork, to ground my opening argument and advance directions for a theopolitical discussion of the touch-event and the politics that might be generated. The first few of these cases relate to the mediatic life of the papacy, in particular that of Pope Francis, the first Latin American and Jesuit pope. I examine these exemplary cases of touch-events in Francis's papacy as mediated affective encounters that transect expected boundaries of, and performatively oscillate between, intimacy and distance, fusing received codes of seduction and sovereignty to ultimately create a renewed form of political charisma. Producing different theopolitical forms and effects, papal touch-events emerge here through a web of histories and contexts: the (contested) sovereignty of the body of the Pope, the fraught politics of undocumented migration in Europe, and the disputed missionary, political, and social terrains of a church dealing with borderlands and their sovereignty. I draw an additional ethnographic case from an impromptu form of collective female blessing given to a priest in the Latin American mission in Rome, who is soon to depart the historical metropolitan 'heart' of Catholicism. The touch-event I read in this blessing breaks with expected gendered ritual conduct and in so doing exposes a space of aporia in a manifestation of sovereignty.

Any account of a touch-event requires an attentiveness to historicity. Touchevents are always the effect of geopolitical and geotheological configurations; 
they respond to, and are enmeshed within, histories of sovereignty and imperial aspirations (Buck-Morss 2007; Trouillot 1995). If theopolitics can help us to unravel some of the implicit secularist biases that have associated the terrain of theology mainly with the domain of the transcendent, it might also allow us to engage anew with how theological discourses, imaginations, and religious manifestations partake in everyday life (here particularly from a perspective of Christianity) and its histories.

\section{On the (Pauline) Touch-Event}

Over the last decade, one strand of anthropology has followed an ethical turn that has been rooted, at least in part, in an interpretation of the Pauline event of conversion. Biblically, the conversion of the Jewish-born and then Apostle Paul is one of the most debated passages of the New Testament. It refers to the moment in which, through the choice to follow the revelation of Jesus's resurrection and the promise of salvation for all, Paul is converted into a member of a new Christian tribe, creating anew the Christian fellowship. The interpretation of this passage has a long and sometimes troubling history, which has been re-engaged over the past two decades in a series of new readings whose impact has registered broadly.

Taken together, these renderings of the Pauline event have stressed not only an agentival action (a purposeful conversion), but also an experience that the subject has (mystically) undergone-an interruption of the given and accepted signification of Jesus's crucifixion, which then gets renewed in a subjective grounding for an imagined whole humanity. The status of this reformed subjective grounding has been the theme of many debates on the Pauline interpretation of the event, not least whether the event is a true psychical re-formation or, once again, the sublimation an old narrative of salvation. As Alain Badiou would argue, the (Pauline) event marks the human capacity to have faith in an external event (beyond the life/death of the single individual) that has the ability to reconstitute a new (universal) subject. The event is the birth of a new language, the resurrection of Christ as a pure beginning that marks the new human subject in a reconstellated division between life and death, spirit and flesh. For Badiou (2003), the historical (not theological) Christian subject becomes an event that breaks into the faithful particularity of the Jewish/ Greek pre-existing condition, making this external event the introjection of a distinct history, the subject-foundation of universalism. Moreover, in a more Lacanian interpretation and partly contrary to Badiou's, the Pauline event divides the subject between a life of obedience to the Law and a 'death drive' desire to escape it (Žižek 2010). That is to say, it is an event that comes to be through an experience of the lack of the Other, as in an experience of doubt 
and abandonment shared with Jesus becoming Christ while feeling abandoned by God on the cross. To sum up, these foci on the Pauline event have brought forward key questions on the nature and the boundaries of the Law, and the immanent-transcendental conditions of subject-making.

Anthropologists have drawn on Badiou's reading of the Pauline event in various ways. His take on the event has been discussed as a universalizing register for ethical subject-making. Via the lens of a universalist subject-making interpretation of Paul, a reading of Pentecostal Christianity, with its dynamic of cultural particularity and rupture of conversion, can be upheld as the analytics for a globalization of religious formations (Robbins 2010). Or, perhaps in a more skeptical take, the Pauline event has been read as an (un)mediated one, devoid of historical particularity and equipped with an infinite, mathematicallike potential for newness (Engelke 2010). These anthropological interpretations have stressed the ethically prismatic effects of the situational event of subject-making (Humphrey 2008).

Building on, while also departing from, these positions, I follow a different reading of Paul that, rather than "leaving aside the emphasis on messianism" (Robbins 2010: 637), puts the messianic aspect of the Pauline event right at the center. This perspective builds upon the work of feminist historians, philosophers, and liberation theologians who have wrestled with the interpretation of the Pauline event through the work of Jacob Taubes and his take on Walter Benjamin's notion of a messianic time (Castelli 2010; Stimilli 2004; Svenungsson 2016).

In opposition to a totalizing Schmittian idea of the inseparability of the spiritual/pneumatic from the worldly/political, Taubes's reading of the Pauline event stresses its messianic dimension, not as the coming of the person of the Messiah, but as that which exceeds the contract of a given Law in the everyday life moment. This is a positionality in/of time from within, a radical bearing toward a given order that unsettles the relation between history and sovereignty-that is, "the relationship of human doing to the realization of the Messianic Reign" (Stimilli 2004: 1). In this interpretation, the Pauline event is not a universalizing, infinite potential for identity, but rather an erasure of a recognition of identity and subjectivity that is impelled by breaking and reframing the Law (in its hegemonic and exclusionary condition) in the now-moment (Jeitzeit), and aligning with what exceeds it. In short, the implication of this second reading of the Pauline event is more socially radical than the strand of the ethical turn in anthropology, which I have mentioned above, may have acknowledged. By extension, it is a more political engagement with a Pauline reading in anthropology-a much needed one, I argue.

Yet why touch? What does touch contribute to a study of the event? There is, of course, an extensive literature on the study of touch. A focus on somatic modes of attention, and beyond, has set us the task of apprehending how 
touch always calibrates different registers of perception, affirming both separateness and connectedness (Barcan 2011: 144) while articulating, especially in clinical settings, certain kinds of medical objects and particular kinds of sensing and knowing subjects. A study of touch-in some forms a haptic vision-also expands from and beyond critiques of regimes of ocular vision. In fact, studies of Christian theological inflections of "medieval touch" show that touch is neither exclusively 'inner' or 'outer' but "aroused, shaped, and modified by rhetorical stimuli" (Largier 2017: 324), producing new aestheses, new forms of perception beyond a given conceptual order. ${ }^{2}$ Historically, then, the Christian touch-in some of its theopolitical forms-becomes the mediated and affective dwelling of an immanent otherwise to the Law (such as the Law identified with the categorical order). Thus, we should ask, how and through which historical 'constellations' (Benjamin 1977) and theological underpinnings does an event become a touch-event? And how might it then disrupt the sovereignty of existing affective infrastructures and, by doing so, be theopolitical? Let me begin to open up these questions through two sets of ethnographic renderings.

\section{Papal Touch-Events}

Pope Francis is the first-ever Jesuit and Latin American pope in the history of the papacy. The overlapping racial and ethnic-political dimensions of Francis's identification as a Criollo Pope from the Americas and as a Jesuit within the context of the contemporary Catholic Church are foregrounded by the ways in which his rhetorical, affective, and charismatic force has been actualized-between, most crucially, proximity and distance, often concretized in a tension between pastoral and theological impulses (Napolitano 2019). Different modalities of Francis's affective actualization have been described with terms such as 'embracing the crowd' and 'conquering America' (Cavadini and Wallenfang 2018). ${ }^{3}$

Yet papal touch-events have also been a source of contestation, for instance, in April 2019 when Pope Francis received the sitting president of South Sudan and some of his oppositional leaders. In a Vatican TV event broadcast from Casa Santa Marta (Saint Martha's House), which the Pope has made his official-unofficial papal residence, Francis exhorted Salva Kiir (the president of South Sudan), Riek Machar (the leader of the opposition and now vice president), and Rebecca Nyandeng De Mabior (the widow of South Sudanese leader John Garang) to devote themselves so that "the fire of the conflict will be extinguished once and for all" (Vatican News 2019a). The diplomats had just signed a revitalized Agreement on the Resolution of Conflict in South Sudan, a document partly masterminded by Cardinal Parolin, the secretary of the Vatican State, in one more attempt to bring a shared plan for peace to the region. In this short, televised speech, Francis addresses their "hearts" in an endeavor 
to make them "brothers," and reminds them to "become simple citizens" while also "fathers of the Nation. Fight within your work [officio]. But in front of the people, hold hands united!" (ibid.). A papal mastery of diplomatic language entrusts them with the "highest vocation to be craft-masters of peace" (O'Grady 2019), searching for peace in a spirit of brotherhood and fraternity through negotiation and forgiveness.

Concluding his entreaty, his voice becoming feebler and feebler due to a long-standing lung deficiency, Francis then breaks all of the expected protocols. He walks toward the Sudanese diplomats, kneels downs, and, with increasing difficulty, kisses their feet, one by one. A palpable silence falls in the room while, visibly moved, Nyandeng De Mabior covers her mouth with her hands. The Pope gets up slowly but steadily and then addresses a final greeting, intertwining a blessing and a diplomatic incitation "that the ethnic and political rifts shall be overcome and that the peace shall be long-lasting, for the common good [bene comune] of all citizens who dream to start to build the Nation" (Vatican News 2019a).

During the days following this broadcast, the press, Catholic leaders, and social media were divided over the significance of this touch-event. While criticizing him as a 'Pope of the Americas', allegedly bringing confusion to and weakening the Church, Francis's detractors also contest his authority on the ground that a pope outside liturgical boundaries should never kiss the feet of mere mortals. The only feet he could kiss would be those of Jesus, from whom he directly descends through Peter the Apostle. Kissing the feet of a group of Sudanese leaders becomes a touch-event, an intensified, mediated mode of being the Church-and a substance of politics. For a conservative strand of the Church, this touch-event is seen as an act of subordination, the excess of a 'heretic' papal figure perceived as misaligned with the 'true' line of sovereign descent incarnated in his predecessors. ${ }^{4}$ In this view, the Pope from America (the first one born outside Europe since the Early Church), with his unscripted touch-events, constitutes a problem of kinship descent within the Catholic Church: his acts and his person are considered an alleged near-heresy within the (metropolitan) line of papal (dis)continuity. The touch-event is here a problem of a continuity of sovereignty of the Law, a challenge to a perceived lineage of kinship descent.

Another papal touch-event had occurred in Loreto, only a few weeks prior to Francis's reception of the Sudanese diplomats. Loreto is a well-known pilgrimage site, believed to contain a part of the house of the Blessed Virgin Mary, relocated via a miraculous intervention from Nazareth to central Italy in the twelfth century. There, after praying to Holy Mary and before celebrating an open-air mass, Pope Francis is greeted by a flock of believers. The first to approach him are a group of Capuchins (the order that cares for this sanctuary site), all of whom bend down to kiss his ring, some holding his hand, some embracing him. 
As believers continue to approach and kiss his papal ring, Pope Francis begins to repeatedly retract his hand from the offered kisses. Beginning with a gentle withdrawal of his right hand, the speed and the awkwardness of withdrawal and the forcefulness of Francis's body language become more and more evident. The rhythm of reporters' flashes intensifies. While the Pope retracts his hands, his smile is frozen in a frenzy of flashes-an index of mediatic intensity. The rather awkward retraction of the hand is serialized in short videos that become viral on social media. The kissing of Francis's papal ring, followed by his awkward withdrawal of his hand, has become a touch-event (Vatican News 2019b). In an interview a few days later, Pope Francis would claim that he withdrew his hands because of concern over hygiene. Yet the withdrawal of the kiss, of an intimate contact in a line of kinship descent, acquires publicity: it becomes a touch-event mobilized by different strands within the Catholic Church.

Kissing the Pope's ring (called the Fisherman's Ring) while bending or kneeling down to the Pope is, of course, not new. It was only in 1958 that Pope John XXIII did away with the bishops' obeisance to the Pope via the kissing of his 'sacred slipper'. In 1975, Paul VI did indeed kiss the feet of Meliton, Metropolitan of Chalcedon, an envoy of the patriarch of Constantinople; but that was clearly an ecumenical gesture of reconciliation, rather than a plea for peace. During the papacy of John Paul II, in particular, kissing the Fisherman's Ring was widely interpreted by the media as an index of a transfer of legitimacy from the head of the Church to the head of a state-especially in his native Poland and in Eastern Europe, before and after the fall of the Berlin Wall (Pobłocki 2004; see also Loaeza 2006).

But how does the theopolitical emerge through these touch-events? Mediatically, such events bring up a central theological hinge of Christianity-the transfiguration of Christ-making it politically enfleshed via the body of the Pope. Enfleshment is a process that de Abreu (in this special issue) points to as an equation of potentialized virtue to repeated, tautological practice. The performativity of the body of the Pope is central here. This is so because his ambiguous availability and unavailability to his flock resonate with the making-present and withdrawing of the body of Christ. In an economic theology of Christianity, the body of Jesus (the corpus verum) withdraws at the moment in which Christ (corpus mysticum) is manifested into the world; thus, the potency of the divine is actually acquired through a manifested act of withdrawal. The papal touch-event, as enacted by investment (by his papal office) and withdrawal, stands within a tension of different and counterpoised theological communicative orders. On one hand, there is what Byzantine iconoclasts would have called the hagion, the public institution of holiness through the sovereign act of prohibition, or what a biblical aesthetic would name Noli me tangere (Touch me not)-the interdiction delivered to Mary Magdalene against touching the withdrawing, resurrected body of Christ. On the other hand, there is what the iconophiles would have 
called the hiéron, the kinesthetic capacity to apprehend the holy via haptic vision and sacred touch (Heo 2018; Mondazin 2005). This accounts for the affective public potency of touch-events. The withdrawal of the papal ring and Pope Francis kissing the Sudanese politicians' feet become touch-events that cannot be grasped unless one engages with their theological underpinnings and the longue durée of their theopolitical force. The publicity of the Pope's withdrawal from a potential kiss of the ring by his flock stands in tension with a long hagion-like theological potency of apprehending the holy via sacred touch.

Moreover, Pope Francis, as a Criollo Pope from the Americas has employed the abrazo (the embrace) not only as a pedagogical tool for the continuity of the Catholic Church and its message, but also as an affective disposition that was not really foregrounded by his Middle European predecessor. Pope Francis has theologically, mediatically, and pastorally foregrounded the importance of touch and the embrace as an encounter with God via the sacrifice of Jesus on the Cross. In his words: "Paradise is not a fairytale place, much less an enchanted garden. Paradise is the embrace of God, infinite Love, and we enter there thanks to Jesus, who died on the cross for us" (Pope Francis 2017; emphasis added). Yet Pope Francis's public embraces and tactility more generally has also been used against him as a sign that he is a 'pastor', rather than a theologian-that he has the power of a shepherd of the flock, rather than the acumen of a distinguished theologian. More than ever before, the current battleground within the Catholic Church-broadly speaking, between conservatives and pro-Francis reformers-is enmeshed in theological underpinnings that emerge ethnographically in touchevents. Let me expand this reasoning through another short example of how a papal touch-event can partake of the political: the case of Lampedusa's crosses.

For his first official papal visit, Francis went to the island of Lampedusa in July $2013 .{ }^{5}$ He appeared to be leaning on and nearly embracing one newly made cross, shaped from the wood of shipwrecked fishing boats that originally carried refugees and undocumented migrants to the Italian shores. These crosses have since become traces of forced mobility, death, suffering, and humanity. By choosing to embrace the Lampedusa Cross in his first official visit as Pope, Francis adopted it as the sign of a particular directionality of his papacy concerning and engaged with issues of human mobility and hospitality. Through the attention given to this 'new' liturgical object, Francis has "communicated his oneness with the plight of migrants" (Catania 2015: 484). In the words of the head curator of the European section of the British Museum where a Lampedusa Cross is displayed, Lampedusa's Crosses mobilize a "politics of seduction." Thus, 'seduction' has become part of the iconographic and haptic movement of these crosses handled, leaned on, and touched by a charismatic Pope from the Americas who blessed the Cross with the motto portatela ovunque (take it everywhere). ${ }^{7} \mathrm{~A}$ theopolitical force from the Americas, condensed in the figure of Pope Francis, was able to traverse and disrupt given trans-Mediterranean borders. 
Since 2013, the Lampedusa Crosses have become a trace of the corpus mysticum of Christ, while also working to 'seduce' believers into action and attentiveness to Italian and European invisibilization (first as empathic) followed by hypervisibilization (then as hostile) of migrant conditions in the Mediterranean. Aesthetic seduction is part of a mystical register too. As discussed in the introduction to this special issue, this is when the force of a corpus mysticum of Christ (as an immanent, yet spectral presence of transcendental value) becomes part of systems of circulation of the flesh, its value, and the forms of labor and excess it produces (Kantorowicz [1957] 1997). In the theological shift of the corpus mysticum from the body of Christ (the Holy Host) to the body of the Church (the Ecclesia) - in twelfth-century Church history-a reminder remains (Mazzarella 2019; Santner 2011). It is this mystical residue of the corpus mysticum of Christ that gives potency to these crosses: they become reliclike traces of life and death, and of an incarnated participation of divine and human in history that calls for justice. Yet a vital residue may also be part of an economics of iconic withdrawal-as in the practice of creating the 'divine' present (the humanness of the Christian God) as forever receding. It is perhaps this theological condition that prompted visitors to notably touch the glass case where a Lampedusa Cross was initially put on display at the British Museum in $2015 .^{8}$ In sum, this reminder can be a theopolitical force expressed in a bordering incarnate process of investment and withdrawal.

A lens on theopolitics then can illuminate the porosity between the ostensibly bounded worlds of the secular and religious political conditions. This aligns in more than metaphorical ways with the broader project of understanding the life of borderlands and the condition of transnationality more generally. While ethnographic borderland studies have allowed for insights into activism and religious conversions (Lucero 2014), immigrant knowledge(s) of the multiple temporal rhythms of the lay of the land (De León 2015), and the economy of extraction produced by an uneven temporality in the circulation of migrant bodies (Andersson 2014), more work is needed to triangulate anthropological, theological, and border studies insights. Anthropologists have been exploring the political ramifications not only of acts of fabulation, such as the substance of the theological imagination (see de Certeau 1992; Mittermaier 2011, 2015; Pandolfo 2018), but also of fabrications of the theological rhythms of everyday life (de Abreu 2015). And if theopolitics brings into view an attention to incarnated borders and a new understanding of the forms that produce the economies within which we are enmeshed (Agamben 2013; Mondzain 2005; Stimilli 2017; Todeschini 2002), it may also provide us with some methodological contributions for a desecularization of border theories. By so doing it may address the unhelpful separation of the domain of the theological from an anthropological study of 'religiosity' - as popular religions at the borderlands (Napolitano et al. 2015). 
If incarnate borders are always emerging through history, then in the case of Pope Francis they are also part of a longue durée of what I refer to as the 'Atlantic Return' of Christianity from the Americas. There has been indeed a steady campaign, particularly from within the Roman Curia, to frustrate and undermine the impact of Francis's proposed reforms, including repeated attempts to rebuff his advocacy of a theology of unconditional hospitality toward undocumented migrants (Ben-Yehoyada 2016, 2017; Napolitano 2017). The papal touch-event of kissing and leaning on the Lampedusa Cross has brought to the fore the position on undocumented migration and hospitality that Francis represents-calling for an interruption of the existing exclusionary law, described as the inability of Italian and European sovereignty to mend the legal hiatus of undocumented migrants at sea. In this sense, the touch-event of the Lampedusa Cross is potentially messianic and-from the perspective of the wing of the Church Francis leads-emancipatory in nature, while potentially undoing long-existing hierarchical and conservative forms of Catholicism at its metropolitan center. Yet histories of Catholicism, (im)migration, and mobility can still be as concealing as they are revealing.

\section{A Gendered Touch-Event}

My final ethnographic rendering comes from the Latin American Catholic mission in Rome and relates to the dimension of theopolitics of contemporary Catholicism that I call the Atlantic Return. As I have written elsewhere (Napolitano 2016), this refers to the flow of people/materialities/labor from Latin America to the metropolitan center of Catholicism in Rome and the Vatican, which is resignifying the same center of Catholicism. The Latin American mission in Rome is attended largely by female migrants from Andean countries, such as Ecuador, Peru, and Colombia, who are mainly employed in the care and housemaid labor sectors. These women form part of a larger wave of Catholic migrants who have rejuvenated church attendance in Rome, interjecting a new spiritual strength into dwindling parishes. The reinvigoration of the metropolitan church with the return of its formerly marginal subjects, however, bears with it deep contradictions. While these new parishioners remain marginalized, both economically and racially, within the space of the metropolitan center, they nevertheless also provide crucial support for conservative strains in the Church. In the face of a perceived plague of secularism and 'moral relativism', the Atlantic Return of Latin American Catholics has strengthened efforts to reaffirm a faith in the Catholic Church as the absolute holder of moral universal truth. This is particularly apparent in the influence of Latin American priests and seminarists studying and working in Rome who belong to more conservative religious orders, such as the Legionaries of Christ (Religion News 
Service 2012). What is important to highlight here, though, is that migrant missions' parishes can become 'hubs' not only for the mediation of laborphysically the place where labor supply meets the demand, in the case of newly arrived migrants) - and a space for different forms of cohesion "within a hyper-diverse urban locality” (de La Ferrière 2018: 398). They are also liturgical spaces for multiple enfleshments and orientations of the sovereign/potent.

In the Church of Santa Maria della Luce, the headquarters of the Latin American migrant mission in Rome, Father J. has just finished celebrating mass for All Saints to a mainly middle-aged group of women, almost all of whom hail originally from Andean countries. Some have moved to Rome recently, while others have been here for quite some time. All have dear dead to remember. The majority of these women are badanti (caregivers) for elderly Romans or work as housemaids in or around the city. For the newly arrived in particular, this church is one of the few public gathering spaces where it is safe to mingle and connect socially outside of a weekly routine that often involves working for and living with employers or holding more than one line of work, with little to no free time.

This evening, Father J., a young Scalabrinian Mexican priest, is celebrating his last mass in the church. He is an energetic, fun, and often hilarious priest, with a very strong Mexican accent. Having been recently posted to Switzerland, he will soon leave this tight-knit group of women who say they have discovered the outdoors and a life in Rome with him. He had introduced them to open-air concerts in the summer, to ice-cream parlors, to strolls in the different parks of the city, and even to a taste of the seaside, in nearby Ostia. He has been more than a safe chaperone for some of the women who have been enduring loneliness and the possibility of desface, a word used in migrant circles to describe a difficult, embodied regime of migrant labor seated in a profound disappointment. A kind of recognizable-by-peers look of 'unhealthy' skin or a bedraggled form of dress, desface is indeed an embodied clash of the horizons of migration and the conditions of living in Rome-an embodied suspension in the 'living here' and now.

At the end of the mass, the flock disperses, but a smaller group of about a dozen women join Father J., who is still at the altar dressed in his mass garments. Spontaneously, they surround him gently in a circle-he laughs, saying that they are "kidnapping him." Suddenly, a woman takes out an indigenous-looking Andean shawl from her bag, which is quickly wrapped around Father J., covering all of his back and part of his head-his head bends down. The women conjointly stretch out their arms and leap toward the center where now Father J. is standing still. One imagines him feeling 'eaten up' by these women's unexpected touch. ${ }^{9}$

These women are trying to make contact with him, all at the same time. Then one of the women starts a prayer-for him to be well in his new post in 
Switzerland, for his health and that of his family in Mexico, for his laughing spirit to never abandon him in his new journey ahead, and that wherever he travels "he will bring the love of the Church." Then some women start to weep silently, while they all stand still, stretching their arms toward/over Father J., who is completely enveloped by the bodies of the women surrounding him. The blessing comes to an end, and, after a moment of stillness, the women begin to disperse. One says that they need to let him "breath again." Another woman, walking down the altar, turns to another and asks: "Qué hemos hecho?" (What have we done?). While church members go to the sacristy to share hot tea and cakes, the irony of the women blessing the priest is not lost on anyone. There is a sense of wonder that something intense has occurred for which there are no adequate words. A touch-event has taken place.

The pastoral catechesis for migrant women has been a thorn in the side of the missionary Catholic Church, and not only in Rome. This is because the Catholic missionary catechesis sees female migrants as sacrificial carriers, able to endure the 'sacrifice' of solitary migration for the good of their families. The catechist pedagogies toward these women reinforce a model of the 'good' migrant (Fiddian-Qasmiyeh 2011). A closer ethnographic engagement in the life of the parish and the life of Latin American Catholic migrants in Rome, however, makes it starkly apparent that migrant women also possess a passionate desire for an emancipatory horizon of migration. This is a yearning to act out a different horizon of life, one that does not fit into a sacrificial paradigm. It involves a curiosity and a longing for a life that is different from the one back home. Desire is enfleshed, and theologically also the open-ended possibility of the resurrected body.

Apostle Paul's rendering of the resurrection has been understood as a process of metamorphosis from seed to plant; hence, multiple corporeality can be an enmeshment of earthly and celestial bodies in the "labyrinth of incarnation" (Rivera 2015: 30). Feminist theologians have critiqued the problematic shortcircuiting between a new spiritual identity of the body of the resurrected Christ and the Christian (Pauline) universal condition, exactly through a different theological reading of the flesh, a metamorphosis of life. Through a reading of the tension between seed and plant, how the force of/in the seed comes into being as the plant-in the biblical Pauline homology with the resurrection of the body (1 Corinthians, 15)-Rivera (2015: 157) argues that social structures should not be conceived in abstraction "but rather as the mechanism by which societies promote the flourishing of some bodies and stifle that of others, distribute life and death. Descriptions of bodies, worlds, and their co-constitutions are creative renderings with material effects." 10

The gendered touch-event that I have described above points to a female force of blessing, one that is enfleshed and that exceeds (and maybe transforms) a given, 'ordinary' liturgical law of the Church. It also making poignantly clear 
the manner in which the Catholic Church is being rejuvenated from within, at its own metropolitan center, by the faith (and labor) of migrant communities. In other words, the touch-event here and within a broader understanding of Catholic Latin American immigration to Italy presents a female potency that cannot be fully contained by the Catholic Church missionary rendering of female migration. It is instead an enfleshed interruption/eruption of a liturgical power that is manifested as a space of aporia: "What have we done?"

\section{Touch-Events and Economies of Virtues}

Touch-events emerge through multiple publics, but not always counter-publics. In the present papacy, Pope Francis still regards a discussion of a transformation of female liturgical power within the Catholic Church as a peripheral concern (O'Connell 2019; San Martín 2018). Examining the role of touch-events through the lens of the theopolitical puts into relief questions that seem as well-worn in the history of emancipatory politics as they do fresh and vital in the context of so many sites of power that appear so strangely fragile amid the tumult of our historical moment. Touch-events can become theopolitical manifestations when they give form (as a movement) and direct potential (as a mode of apprehension) for both emancipation and transformation of the law. Yet they can also mobilize a re-entrenchment of forms of sovereignty that have a long and enduring history of hierarchical formations. As I hope is clear by now through the examples I have explored, a theopolitics of the touch-event, with its irruptive, potentially heretic, and seductive nature, is manifold: it is both emancipatory and subjugating, exceeding and enveloping.

Let me spell out that my thinking here is not meant to validate, once more, the explanatory power of theologically infused (Christian) universal perspectives, but rather to help put into focus some of the theological underpinnings of enfleshed formations of power that we may be embedded into. In this sense, some of the theopolitical inflections imbricated in our ethnographic and anthropological encounters of touch-events and the carnalities of intimacies and distance, seduction and sovereignty, that they produce should be studied not only as ethical conditions of subject-making in a frame of (dis)continuous time and cultural rupture. They should also be grappled with through a sensitivity to the messianic limits of the Law as an irruption/aporia into the present (to recall Taubes here) and its condition of enfleshment.

Touch-events can come into being only through the theopolitical substance of different historical constellations. In the cases I have presented here on the Atlantic Return-focused on the first Latin American (and Jesuit) Pope and on female Latin American migrant laborers-we encounter the touch-event directed through, respectively, the body 'sitting on the throne' of Christianity 
and those who are rejuvenating the faith of Europe from its margins. Both cases present a theopolitical touch-event that at once disrupts and revitalizes the sovereignty of existing affective infrastructures of holiness and labor. The alleged betrayal of a perceived transcendental truth, as the unchanging root of the Petrine ministry, and the apophatic moments intrinsic in the force of a Theos in movement are constantly localized via multiple gendered and racialized enfleshments. My examples here point to how a theopolitics of touch-events is created of a constant tension between proximity and distance, sovereignty and seduction, within a long-standing theological conundrum of making the divine present/withdrawing.

Moreover, if the touch-event is here also a problem of sovereignty, a challenge to a perceived lineage and ritual reproduction, it can also serve as a tool to understand how ethnographic encounters and the 'poetics of the flesh' (Rivera 2015) enable an important engagement with global Christianity. It suggests a critical engagement that is not a return to the local-empirical or to a cultural rupture (as universal/global) that effaces a longue durée of affective histories (Comaroff 2010: 529). Rather, it is an engagement that moves our analytics beyond an ethics of affordances toward economies of virtues, that is, from an ethics of subject-making and an accent on matter rendered through affordances as "special characteristics of human sign-using capacities" (Keane 2014: S318) ${ }^{11}$ to an attention to economies of virtues that are theopolitically incarnate. The potency of touch-events is indeed incarnate-with incarnation, once again, as the unpredictable process of investment and withdrawal, generated between the human and the more-than-human while partaking in justice and history.

Enfleshed and affective histories, such as the Atlantic Return from the Americas, allow us to see touch-events not only as a magnifying glass of intimate encounters. They also explain how incarnate histories may disrupt or reinforce given socio-political (b)orders while also disrupting and reinstating the Law. And with and beyond the Law more broadly, they help us to further post-secular (b)order theories by extending our ethnographic understandings to miraculous potentialities, the struggles against, and the excesses of always provisional formations of sovereignty from below (see the introduction to this special issue). If the Law, as Derrida (1989-1990: 933) argues, "is transcendent and theological, and so always to come, always promised, because it is immanent, finite and thus already past," then a study of the theopolitical force of touchevents may be a good starting point for grasping familiar and unfamiliar radical (emancipatory, subjugating, carnal) ways to dwell in and enliven the world and its borders. 


\section{Acknowledgments}

Heartfelt thanks to all the wonderful contributors to the intellectual journey-incommon that has brought this special issue to life since a workshop held on the theme at the University of Toronto in 2017. Particular appreciation is extended to my co-editor, Carlota McAllister, for her sharp insights and remarkable collegial generosity. Support for this research was given by the Social Science and Humanities Research Council of Canada. All faults in this piece are, of course, my own.

Valentina Napolitano is a Professor of Anthropology and a Connaught Scholar at the University of Toronto. She works on Critical Catholic Studies, political theology borderlands and migration, affective histories, holy infrastructures, and anthropology of traces. She is the author of Migrant Hearts and the Atlantic Return (2016) and Migration, Mujercitas, and Medicine Men (2002), and co-editor of The Anthropology of Catholicism: A Reader (2017, with Kristin Norget and Maya Mayblin). She is the co-recipient of a Connaught Global Challenge Award for a research project titled "Entangled Worlds: Sovereignty, Sanctities and Soil," and is currently working on a project on the Catholic Church and holy infrastructures at the Detroit-Windsor corridor. E-mail: v.napolitano@utoronto.ca

\section{Notes}

1. For more on TouchEvent, see "Mozilla MDN Web Docs." at https://developer. mozilla.org/en-US/docs/Web/API/TouchEvent.

2. See also the work of other medievalist historians, such as Caroline Walker Bynum (2011) and Amy Hollywood (2010), on apophatic aesthesis and the desecularization of critical theory.

3. This is also the case of the branding of the rosary in public speech by Italian Deputy Prime Minister Matteo Salvini, who has openly rebuffed Pope Francis in the name (actually literally) of his predecessor Benedict XVI. See "Salvini elogia le nuove t-Shirt contro Papa Francesco: 'Chi apre agli imam non mi piace' [Salvini praises new T-shirts against Pope Francis: 'I don't like those who are open to imams']," La Repubblica Milano, 18 September 2016. Unless otherwise indicated, all translations are my own.

4. The conservatives' consternation is also part of a wider angst over a perceived lack of magisterial firmness in dealing with scandals that are plaguing the Roman Catholic Church (Pope Benedict XVI 2019).

5. The island of Lampedusa has become a multifaceted index of the necropolitics of the Mediterranean (see, e.g., De Genova 2013; Rosas 2019). In its reengagement with undocumented migration, it is seen, perhaps in an excess of signification, as a prophetic land. As Gioacchino Campese (2012: 25) puts it: 
"Lampedusa has thus become for Italy, and indeed for Europe, a symbol of the complexity and the drama of migration ... [I]t is precisely in what happens on and around this island that the future of Europe will be decided."

6. Personal communication with Jill Cook, the head curator of the British Museum, in June 2016.

7. I can only gesture to the fact that a politics of seduction reverberates with a neo-baroque aesthetics circulating to and from the Americas, part of a "transhistorical mobile aesthetic" (Norget 2017: 189) and an intimate/public affective architecture. The neo-baroque is mediative in a scalar and almost fractal fashion, absorbing contrasting elements and opposed forces while masking them, altering awareness and sensations, and having compelling material effects on those who engage with it.

8. Personal communication, Jill Cook, June 2016.

9. I use the term 'eaten up' here to echo the metaphor used by Cardinal Scola. Recounting a moment during Pope Francis's 2017 visit to Naples, Scola described Francis being surrounded by local cloister nuns (traveling under a special permit to leave the convent to bring Pope Francis presents). As Scola put it, in a heap of joy they nearly "ate him up."

10. For Paul, this metamorphosis is guided by the external force of the glory of God.

11. See here, for a critique of Weber's take on Protestantism as the classic frame to understand the birth of the spirit capitalism - also a starting point of many works on Anthropology of Protestant Christianity-the work on capitalism and Italian medieval guilds' virtues of Amintore Fanfani ([1944] 1984). I wish to thank Filippo Osella for pointing out this.

\section{References}

Agamben, Giorgio. 2013. The Highest Poverty: Monastic Rules and Form-of-Life. Trans. Adam Kotsko. Stanford, CA: Stanford University Press.

Andersson, Ruben. 2014. "Time and the Migrant Other: European Border Controls and the Temporal Economics of Illegality.” American Anthropologist 116 (4): 795-809.

Badiou, Alain. 2003. Saint Paul: The Foundation of Universalism. Trans. Ray Brassier. Stanford, CA: Stanford University Press.

Barcan, Ruth. 2011. Complementary and Alternative Medicine: Bodies, Therapies, Senses. Oxford: Berg.

Benjamin, Walter. 1977. The Origin of German Tragic Drama. Trans. John Osborne. London: NLB.

Ben-Yehoyada, Naor. 2016. “'Follow Me, and I Will Make You Fishers of Men’: The Moral and Political Scales of Migration in the Central Mediterranean." Journal of the Royal Anthropological Institute 22 (1): 183-202.

Ben-Yehoyada, Naor. 2017. The Mediterranean Incarnate: Region Formation between Sicily and Tunisia since World War II. Chicago: Chicago University Press. 
Buck-Morss, Susan. 2007. “Visual Empire.” Diacritics 37 (2-3): 171-198.

Bynum, Caroline Walker. 2011. Christian Materiality: An Essay on Religion in Late Medieval Europe. Brooklyn, NY: Zone Books.

Campese, Gioacchino. 2012. "The Irruption of Migrants: Theology of Migration in the 21st Century." Theological Studies 73 (1): 3-32.

Castelli, Elizabeth A. 2010. “The Philosophers' Paul in the Frame of the Global: Some Reflections.” South Atlantic Quarterly 109 (4): 653-676.

Catania, R. Tina. 2015. "Making Immigrants Visible in Lampedusa: Pope Francis, Migration, and the State.” Italian Studies 70 (4): 465-486.

Cavadini, John C., and Donald Wallenfang, eds. 2018. Pope Francis and the Event of Encounter: Global Perspectives on the New Evangelization. Eugene, OR: Pickwick.

Comaroff, John. 2010. "The End of Anthropology, Again: On the Future of an In/ Discipline.” American Anthropologist 112 (4): 524-538.

de Abreu, Maria José A. 2015. "Worldings: The Aesthetics of Authority among Catholic Charismatics in Brazil.” Culture and Religion 16 (2): 175-192.

de Certeau, Michel. 1992. The Mystic Fable. Vol. 1: The Sixteenth and Seventeenth Centuries. Trans. Michael B. Smith. Chicago: University of Chicago Press.

De Genova, Nicholas. 2013. "Spectacles of Migrant 'Illegality': The Scene of Exclusion, the Obscene of Inclusion.” Ethnic and Racial Studies 36 (7): 1180-1198.

de La Ferrière, Alexis Artaud. 2018. "Somewhere between Love and Justice: A Roman Catholic Church in Paris Responds to the European Migration Crisis." International Journal of Politics, Culture, and Society 31 (4): 397-417.

De León, Jason. 2015. The Land of Open Graves: Living and Dying on the Migrant Trail. Oakland: University of California Press.

Derrida, Jacques. 1989-1990. "Force de loi: Le 'fondement mystique de l'autorité”” [Force of the law: The 'mystical foundation of authority']. Cardozo Law Review 11: 920-1045.

Engelke, Matthew. 2010. "Number and the Imagination of Global Christianity; or, Mediation and Immediacy in the Work of Alain Badiou." South Atlantic Quarterly 109 (4): 811-829.

Fanfani, Amintore. [1944] 1984. Catholicism, Protestantism, and Capitalism. Notre Dame, IN: University of Notre Dame Press.

Fiddian-Qasmiyeh, Elena. 2011. "Introduction: Faith-Based Humanitarianism in Contexts of Forced Displacement.” Journal of Refugee Studies 24 (3): 429-439.

Firth, Raymond. 1940. "The Analysis of Mana: An Empirical Approach.” Journal of the Polynesian Society 49 (4[196]): 483-510.

Graeber, David, and Marshall Sahlins. 2017. On Kings. Chicago: HAU Books.

Heo, Angie. 2018. The Political Lives of Saints: Christian-Muslim Mediation in Egypt. Oakland: University of California Press.

Hollywood, Amy. 2010. "Spiritual but Not Religious: The Vital Interplay between Submission and Freedom." Harvard Divinity Bulletin 38 (1-2). https://bulletin. hds.harvard.edu/articles/winterspring2010/spiritual-not-religious.

Humphrey, Caroline. 2008. "Reassembling Individual Subjects: Events and Decisions in Troubled Times.” Anthropological Theory 8 (4): 357-380. 
Kantorowicz, Ernst Hartwig. (1957) 1997. The King's Two Bodies: A Study in Mediaeval Political Theology. Princeton, NJ: Princeton University Press.

Keane, Webb. 2014. "Rotting Bodies: The Clash of Stances toward Materiality and Its Ethical Affordances.” Current Anthropology 55 (S10): S312-S321.

Largier, Niklaus. 2017. “The Media of Sensation.” In Norget et al. 2017, 316-325.

Loaeza, Soledad. 2006. "Vicente Fox's Presidential Style and the New Mexican Presidency.” Mexican Studies 22 (1): 3-32.

Lucero, José Antonio. 2014. "Friction, Conversion, and Contention: Prophetic Politics in the Tohono O'odham Borderlands.” Latin American Research Review 49: 168-184.

Mazzarella, William. 2019. "The Anthropology of Populism: Beyond the Liberal Settlement.” Annual Review of Anthropology 48: 45-60.

Mittermaier, Amira. 2011. Dreams That Matter: Egyptian Landscapes of the Imagination. Berkeley: University of California Press.

Mittermaier, Amira. 2015. "How to Do Things with Examples: Sufis, Dreams, and Anthropology." Journal of the Royal Anthropological Institute 21 (S1): 129-143.

Mondzain, Marie-José. 2005. Image, Icon, Economy: The Byzantine Origins of the Contemporary Imaginary. Trans. Rico Franses. Stanford, CA: Stanford University Press.

Napolitano, Valentina. 2016. Migrant Hearts and the Atlantic Return: Transnationalism and the Roman Catholic Church. New York: Fordham University Press.

Napolitano, Valentina. 2017. “'The Globalization of Indifference’: On Pope Francis, Migration and Global Acedia." In Religion and the Morality of the Market, ed. Daromir Rudnyckyj and Filippo Osella, 263-284. Cambridge: Cambridge University Press.

Napolitano, Valentina. 2019. "Francis, a Criollo Pope." Religion and Society: Advances in Research 10: 63-80.

Napolitano, Valentina, Nimrod Luz, and Nurit Stadler. 2015. "Introduction: Materialities, Histories, and the Spatialization of State Sovereignty." Religion and Society: Advances in Research 6: 90-97.

Norget, Kristin. 2017. "The Virgin of Guadalupe and Spectacles of Catholic Evangelism in Mexico.” In Norget et al. 2017, 184-200.

Norget, Kristin, Valentina Napolitano, and Maya Mayblin, eds. 2017. The Anthropology of Catholicism: A Reader. Berkeley: University of California Press.

O’Connell, Gerard. 2019. "Pope Francis Tells Women Religious Church Cannot Alter Revelation on Women's Diaconate.” America, 10 May. https://www. americamagazine.org/faith/2019/05/10/pope-francis-tells-women-religiouschurch-cannot-alter-revelation-womens-diaconate.

O’Grady, Siobhán. 2019. “It’s Exceedingly Rare for the Pope to Kiss Feet. He just did it for South Sudan's Warring Leaders.” Washington Post, 12 April. https://www.washingtonpost.com/world/2019/04/12/bid-peace-popefrancis-hosts-south-sudans-warring-leaders-spiritual-summit-kisses-theirfeet $/$ ?noredirect $=$ on\&utm_term $=$. aba33883f121. 
Pandolfo, Stefania. 2018. Knot of the Soul: Madness, Psychoanalysis, Islam. Chicago: University of Chicago Press.

Pobłocki, Kacper. 2004. "Europe, the Pope and the Holy Left Alliance in Poland." Focaal 43: 121-133.

Pope Benedict XVI. 2019. “'The Church and the Scandal of Sexual Abuse.” Catholic News Agency, 10 April. https://www.catholicnewsagency.com/news/ full-text-of-benedict-xvi-the-church-and-the-scandal-of-sexual-abuse-59639.

Pope Francis. 2017. “General Audience.” Vatican Website, 25 October. http:// www.vatican.va/content/francesco/en/audiences/2017/documents/papa-francesco_20171025_udienza-generale.html.

Religion News Service. 2012. "Pope Benedict XVI Confronts Secularism with Synod of Bishops on 'New Evangelization.”” Huffington Post, 9 October. https://www.huffpost.com/entry/pope-benedict-xvi-secularism_n_1949751.

Rivera, Mayra. 2015. Poetics of the Flesh. Durham, NC: Duke University Press.

Robbins, Joel. 2010. "Anthropology, Pentecostalism, and the New Paul: Conversion, Event, and Social Transformation." South Atlantic Quarterly 109 (4): 633-652.

Rosas, Gilberto. 2019. “Necro-subjection: On Borders, Asylum, and Making Dead to Let Live." Theory \& Event 22 (2): 303-324.

San Martín, Inés. 2018. “Pope Reaffirms Women Can’t Be Priests, Says Church has 'Woken Up' on Sex Abuse.” Crux, 20 June. https://cruxnow.com/vatican/2018/06/pope-reaffirms-women-cant-be-priests-says-church-has-wokenup-on-sex-abuse/.

Santner, Eric L. 2011. The Royal Remains: The People's Two Bodies and the Endgames of Sovereignty. Chicago: University of Chicago Press.

Stimilli, Elettra. 2004. Jacob Taubes. Rome: Morcelliana Editrice.

Stimilli, Elettra. 2017. The Debt of the Living: Ascesis and Capitalism. Trans. Arianna Bove. Albany: State University of New York Press.

Svenungsson, Jayne. 2016. Divining History: Prophetism, Messianism, and the Development of the Spirit. Trans. Stephen Donovan. New York: Berghahn Books.

Todeschini, Giacomo. 2002. I mercanti e il tempio: La società cristiana e il circolo virtuoso della ricchezza fra Medioevo ed età moderna [Merchants and the temple: Christian societies and the virtuous circle of wealth from the Middle Ages to the modern period]. Vol. 11. Bologna: Il Mulino.

Trouillot, Michel-Rolph. 1995. Silencing the Past: Power and the Production of History. Boston: Beacon Press.

Vatican News. 2019a. "Papa Francesco-Leaders del Sud Sudan 2019-04-11” [Pope Francis-Leaders of South Sudan 2019-04-11]. YouTube video, 33:29 min., 11 April. https://www.youtube.com/watch?v = DcqBSI1ejv4.

Vatican News. 2019b. “Papa Francesco Loreto-Incontro Fedeli 2019-03-25” [Pope Francis Loreto, meeting with the faithful flock 2019-03-25]. YouTube video, 2:42 min., 25 March. https://youtu.be/J3KU_JSoUwo.

Žižek, Slavoj. 2010. "Paul and the Truth Event.” In Paul's New Moment: Continental Philosophy and the Future of Christian Theology, ed. John Milbank, Slavoj Žižek, and Creston Davis, 74-99. Grand Rapids, MI: Brazos Press. 